In J. B. Saunders, E. Fiddian-Qasmiyeh and S. Snyder (eds). 2016. Intersections of Religion and Migration: Issues at the Global Crossroads. New York: Palgrave Macmillan, pp. 71-90.

\title{
Living Religious Practices
}

\author{
Kim Knott
}

\section{Introduction}

Migration has consequences for how religions are lived in practice. Religious traditions provide resources for people as they prepare to migrate, make their journeys, arrive and settle, establish themselves in new contexts and negotiate their minority status and rights. These resources do not escape unchanged in the process of migration, however. Even highly prized reminders of home and earlier times may be subject to re-examination, adaptation and innovation. Moving to a different location and new life alters a person's relationships and memories. Migrants revise their perspective on things previously taken for granted. That which was tacit may now be brought to consciousness; it may require explanation; it may need refashioning for a new time and place, and for different ends. But migration — perhaps particularly for refugees from conflict zones and those cut off from return - may also engender a need for stability, and thus the reproduction of familiar norms, structures, discourses and practices.

To the tensions between change and continuity, and renewal and conservation, can be added new possibilities for agency in tension with both traditional and novel sources of domination and conformity. The social and geographical dislocation brought about by migration creates opportunities for innovation in religious identity and practice. Second and third generation settlers and even some new migrants, however, will be situated within long-standing communities operating with well established, sometimes rigid patterns of authority, customs and values in which room for cultural and social maneuver may be limited. Strong transnational familial ties may exacerbate this. And to it must be added those laws, policies, norms and practices imposed by the receiving state and its institutions on newcomers and citizens. 
Furthermore, the sheer variety and complexity of migrant autobiographies exacerbate the shifting sands of everyday religiosity. As Straut Eppsteiner and Hagan (in this volume) show, migrant motivations and preparations for travel involve a range of locally specific religious practices, including those carried out by friends and family left behind. These are followed by those conducted on route, in addition to others associated with arrive and settlement. Religious beliefs and practices, and the psychological and emotional succor they provide, together operate as a "powerful guiding, coping, protective, and mediating force" for migrants. ${ }^{1}$

\section{Migrant Religious Practice: Types, Scales and Conditions}

This chapter focuses on the place of religion in the conduct of everyday migrant life. This involves not only a consideration of calendrical and customary religious rituals carried out in the home, places of worship and elsewhere, but also of those quotidian practices informed by religious beliefs, norms and values. These include those related to food preparation, children's nurture, dress, healthcare, shopping, and social interactions with familiars and strangers. ${ }^{2}$ In addition, the selfconscious adoption of new spiritually motivated disciplinary regimes and participation in boundary crossing practices, such as interfaith or multicultural events, is also relevant. The table below gives examples of these different types, all of which may operate across a range of scales, from the individual and familial, communal and societal, through to the transnational and global.

\section{Table 3.1: Living religious practices: examples and scales}

With reference to these types and scales, I will turn in later sections to various cases which illustrate the ways in which individual migrants and migrant minorities draw on religious practices to express and cope with their condition, to connect with others in and beyond their communities, to make public claims and innovate. The examples come from research conducted between 2006 and 2010 on the religious lives of migrant minorities in urban Malaysia, South Africa and the United 
Kingdom. ${ }^{3}$ Imperially and colonially connected, these sites were seen nonetheless to offer rather different contexts of diversity, the negotiation of religious identities and religious place-making. ${ }^{4} \mathrm{~A}$ biographical research methodology was adopted in order to explore how Islamic, Christian, Hindu, Buddhist and Chinese religious meanings, practices, and organizations reflected and informed individual migrants' identities, affiliations, and approaches to living within new societies. Their narratives expressed the experiences and activities of individuals as they moved in their daily lives between different spheres of operation, from locally-rooted family life through to transnational networking. Cultural competency across a range of scales was witnessed, as was the mobility and circulation of religious people, things and practices, all filtered through the medium of the personal biography.

Before drawing on these narratives for examples of religious practice, however, several points of a more general nature are worthy of note. They are addressed to various degrees in recent research on migration and everyday religion and its spaces, and they pertain irrespective of the migrant group, religion and sending or receiving society.

First, practice is inseparable from discourse. Even though the focus in this chapter is on what migrants do, this cannot meaningfully be separated from what they say or what others say or do about them. ${ }^{5}$ The discursive context inevitably informs practice, as Stringer's example of the dynamic discourse and practice of interreligious solidarity in one Birmingham neighborhood during Britain's 2011 riots suggested. ${ }^{6}$ Second, practices constitute and shape private and public spaces, as well as themselves being informed by the contexts and places in which they are enacted. ${ }^{7}$ Tweed's account of the journey by sea of Our Lady of Charity from Cuba to Miami in 1961 and the consecration of her shrine by Miami's Cuban Catholics some twelve years later demonstrates the mutual relationship between practices and their places. ${ }^{8}$ Third, religious practice involves the use and manipulation of power. Rituals and routines may be carried out in order to acquire, contain, manage or fend off power. The choice of practices and the meanings attributed to them may be 
constrained by authorizing traditions, leaders or representatives, as well as being shaped by individual agency. ${ }^{9}$

Fourth, although different scales of practice have been identified above for methodological reasons, in practice the boundary between private and public is increasingly difficult to maintain when it comes to analyzing ritual in general, including the performance of religious practices. ${ }^{10}$ Contemporary choices about how to dress, whether to cover one's head and where religious or spiritual practices should be conducted have implications no less for public space and discourse than for individuals and families. Therefore, fifthly, religious practice is bound up with identity, identification and the politics of recognition, as a consequence of which those studying these issues should not neglect the ways in which practices are enacted strategically or tactically in order to assert, challenge, discipline, subvert or make space for change. ${ }^{11}$ These concepts of strategy and tactics — invoked by Michel de Certeau in his theorization of the practice of everyday life — have allowed scholars of religion to debate the nature of everyday lived Islam, with Linda Woodhead noting that in an age of time/space compression "rituals, beliefs and symbols are cut loose from their old containers and become free-floating as never before," with strategic and tactical forms of religion continually informing one another. ${ }^{12}$

Finally, from a scholarly perspective, how we choose to research living religious practices is likely to shape the conclusions we draw about them. If we enter the subject of religious practice through the place of worship — as I did as a doctoral student when I studied Hindu religious practice in Britain - then our conclusions may pertain primarily to the communal scale, whereas if interviews, autobiographies and life histories are our chosen methods, then what individuals do, believe and think about their practices will come to the fore. ${ }^{13}$ If the nation state, public sphere or citizenship is our entry point, then religious practices may be seen as statements of intention or identity, as demands for recognition or space, or as resources for integration or civic encounter. ${ }^{14} \mathrm{~A}$ transnational or diasporic gaze may change the focus to one of the movement and circulation of practices and the people and things associated with them. ${ }^{15}$ 
In the remainder of the chapter, with examples from the religious lives of minorities in South Africa, Malaysia and London, I discuss how migrants enact religious practices in the process of (a) facilitating migration and settlement, (b) forming and bonding persons and communities, (c) making claims and securing public spaces, and (d) crossing boundaries and performing cosmopolitanism.

\section{Facilitating Migration and Settlement}

Martin, a Nigerian migrant who traveled to South Africa in 2005 after being told by God that Johannesburg was to be his "divine destination," sought the resources and help he needed to first migrate and later remain through prayer and fasting. ${ }^{16}$

Praying is my food; it is the food I almost eat [every] day. I like prayer. It is prayer that helped me come to South Africa. It is prayer that got me a flight ticket ... that let them allow me to enter ... God allowed it to happen. ${ }^{17}$

As a member of Mountain of Fire and Miracles Ministries (MFM), a Nigerian-based "do-it-yourself Gospel ministry," Martin prays for "the power to prosper," "for new beginnings," "destiny preservation," for "breaking stubborn curses" and opposing "evil patterns." ${ }^{18}$ He finds prayer to be a practice that can effect positive change and overcome negativity and resistance. It can be harnessed to purify, discipline, convert, and protect the self from the temptations of the flesh, from those demonic powers that are believed to dominate Johannesburg and other cities. ${ }^{19}$ Through their theologies of deliverance and aggressive prayer practices, MFM and other Nigerian Pentecostalist and Charismatic churches empower migrants, like Martin, to account for and contend with the challenges and misfortune brought about by migration and the new context. ${ }^{20}$

But prayers in Johannesburg always connect back to those at MFM's "Prayer City," a church complex on the Nigerian Lagos-Ibadan Expressway where prayer goes on all day, every day. Thus, although for MFM and its members prayer is a personal act, an intimate and embodied performance linking believer and God, it is also transnational — part of a 'chain of prayer' 
performed at various points along religious and migrant networks - as well as supra-territorial, connecting those who pray with the Kingdom of God. ${ }^{21}$ As another MFM migrant put it, "it does not say in the Bible that my nationality is South African. It says my nationality is in heaven."22

The connection by pious migrants of journey, identity and destiny with practice can also be witnessed in the words of Ahmed, a London-based Bangladeshi migrant and member of the global Islamic revivalist movement, Tablighi Jama'at:

But we send groups all over the world, at our own expense... When you go to different areas, you get experience. You get experience of the locality in the particular country. Spiritually it's called hijra. This makes you perfect, because you sacrifice for your religion. So when you sacrifice your home, your business, your children, your wife, for the din (faith), for Islam, you get more suab (blessings/rewards). Our Prophet's birthplace was Mecca, but his grave was in Medina...So he made hijra and he went to so many places in the Middle East. So it is our duty also, to travel. ${ }^{23}$

Through the theological concepts of sacrifice and the Prophet's migration (hijra), Ahmed links local and global scales, relinquishing home and family for the greater goods of faith, duty and blessings in the practice of religious travel. Tablighi Jama'at is not merely a religion carried by people on the move. ${ }^{24}$ It is a "travelling faith," a de-territorialized religious movement with a universal message whose members are charged to travel in order to proselytize. ${ }^{25}$ As such it makes a particular virtue of the connection between migration and mission, sacralizing the former and giving it divine purpose.

Religions travel through migrants, but also with them. It also travels to them in their places of settlement. The extent and success of this depends on the portability of their leaders, representatives, and spirits, as well as their rituals, ideas, objects and symbolic places. ${ }^{26}$ In so far as they are able to travel and relocate, such people, ideas and things may become key resources in the conduct of practices that ease the journey, arrival and settlement of migrants. For Vásquez, Latin American and African Christianities, like MFM, are a case in point: "their worldviews, practices 
and organizational morphologies not only make sense of the contradictions of this 'gated globe' but actually thrive on these contradictions" of movement and connection. ${ }^{27}$ Other religious groups, however, may be hampered by theological restrictions on travel or the vernacular nature of their organization and practices. Jains are one such example whose orthodox traditions "work against globalization", if the latter is understood as those practices involving the free movement of people, goods, capital, information and so on around the world. ${ }^{28}$ Their texts and practices, according to Flügel, "explicitly discourage long-distance travel and unlimited expansion of the spheres of action." ${ }^{29}$ There are exceptions, however: Swaminarayan Hinduism, with its very particular Indian Gujarati history and use of the Gujarati language, has globalized successfully, though largely among diaspora Gujaratis who have been active economic migrants. ${ }^{30}$

The ability to handle the contradiction of movement and connection can be witnessed in the testimonies of those Congolese Kimbanguist migrants interviewed by David Garbin who reflected on the recreation of the lingomba, the community of the church, in London in the early $1990 \mathrm{~s} .{ }^{31}$ At this time, prophecies from the spirits (milimo) of Simon Kimbangu and his sons were conveyed to followers by female mediums (mamans basadi). The spirits appeared during prayer times and Sunday services, with séances becoming increasingly organized and ritualized, and with sacred elements - water and earth from the Congolese Holy City of Nkamba — used for healing. ${ }^{32}$ Spirits, words and objects connected London-based migrants with the divine world (through the sacred pivot of Nkamba), reflecting and legitimizing their diasporic experience, and "providing a way to negotiate the consequences of migration, the sense of loss and the cultural shock." ${ }^{, 33}$ Until these gendered practices of possession and prophecy were officially challenged and outlawed in 2002, many church members understood the milimo and their female mediums to be channeling divine assistance, moral guidance and authority to migrants and those seeking asylum.

Thanks to the milimo, we were successful with the papers...For example, you have been rejected and you need to leave the country, when you see her [the medium], you pray and she would tell you what to do and to pray, to adopt a good Christian behaviour [sic]. 
Her prayers will help you to get the papers. Nobody in our parish was deported [expulse] because of absence of legal documents, nobody. ${ }^{34}$

In all three examples, practitioners understood their actions diasporically — as connecting to imaginaries of the past, the homeland, and divine places — or as an expression or response to their migrant condition. They saw the individual and communal performances of prayer, fasting, travel, possession and prophecy as the means to facilitate change and bring about successful moral and practical outcomes, often as quotidian but nonetheless life-changing as getting a visa, acquiring the money needed to stay or getting a job.

\section{Forming and Bonding of Persons and Communities}

"Migrants" and "migrant communities" are brought into being, constituted and sustained through a variety of practices. Some of these are performed by the state as migrants cross borders, enter territories, seek work and housing or attempt to access education, healthcare and other services. Majority and other minority populations also contribute to their formation, as they categorize or engage with migrants as others. However, migrants contribute to these processes themselves though a variety of cultural practices, not least of all those religious activities pertaining to the production, purification and adornment of bodies, organizations and the built environment, and to the celebration and transmission of rituals relating to the life-cycle and the annual calendar. And, as we saw in the previous example, gender plays no small part in this.

This is illustrated in case studies of two Hindu minorities, the first from South Africa and the second London, in which bodies, homes and temples become sites of individual and collective identity formation. ${ }^{35}$ In the first, Thomas Blom Hansen describes how the lost ideal Indian home, rather than the temple, has been recreated in order to construct "proper Indianness" and to connect people visibly with their heritage. ${ }^{36}$ Houses and gardens have been improved with outdoor and indoor features emblematic of Hindu myth, ritual and iconography, such as shrines, jhanda (poles with colored flags linked to Hindu deities), paintings of gods and goddesses, and brass and gold 
ornaments; their layout has been altered to replicate, often in confined spaces, "traditional" homes designed for large multi-generational family gatherings.

Bodies too have provided an opportunity to mark Indianness, especially by women through the wearing of saris and shalwar kameez, bindis and bangles rather than other local forms of dress. Not surprising then that, along with the interior decoration of homes, bodies have become sites on which battles of religious identity and conversion are enacted. When Hindus convert to Christianity, they are encouraged to erase ostensibly Hindu ornamentation, to revise their discourse on dress, modesty and adornment and to remove any objects that might "attract demons" (because of their association with Hinduism), with the goal being "to bring about a more systematic separation of Christian and Hindu life worlds, networks and families. ${ }^{, 37}$ New bonds supplant old ones, with Christian congregations replacing kinship groups in the operation of discipline and surveillance.

In the second case, from Ann David's research on the practices of Tamil Hindu migrants at a Sakthi Peetham or worshipping center in London, bodies, homes and temples are connected locally and transnationally in the making of individuals and communities. ${ }^{38}$ This center is one of many shrines worldwide, dedicated to the Goddess Adhiparasakthi, that honors her male intermediary, Bangaru Adigalar, but allows lay women to take full responsibility for worship and management. The devotional rituals at the East Ham Peetham emerge from South India, "through an umbilical link to the Melmaruvathur Adhiparsakthi Siddhar Peetham," writes David, drawing on a gendered metaphor of childbirth. Many of London's women devotees have visited the temple in India, and their habitual domestic and temple practice reflects what takes place there. ${ }^{39}$ David notes that they embody devotional worship through a variety of practices, including the circumambulation of the shrine on their knees, full bodily prostrations, washing the guru's feet, chanting, making kolams (Tamil floor designs) and preparing food. ${ }^{40}$

Communal practice is also informed by the parent temple with regular and calendrical events formalized and their details transmitted to centers elsewhere. Three distinctive weekly pujas are held, and special occasions tailored to the goddess, Sakthi, and the guru are added to the annual 
festive calendar. ${ }^{41}$ In all of these, women practitioners participate fully, not relying on traditionallytrained Sanskritic Brahmins, but carrying out the rituals for themselves. At the Chitra Purnami festival in 2008 "each worshipper had [her] own small flame, a replica of the larger central fire, to which they offered clarified butter (ghi), flowers, and fruit." ${ }^{, 2}$ This pattern of innovative practice, in addition to making space for individuals to acquire ritual expertise, brings people together, and transmits and rehearses embodied knowledge to newcomers and later generations, as well as providing worshippers with opportunities for transcendence.

But does formative practice of this kind have a special or distinctive role or function for migrants and new settlers, particularly women? Migrants are said to accumulate and deploy social capital for the purposes of bonding (to other like-minded or related people), bridging (connecting horizontally to outsiders) and linking (vertically to public sources of power, to government etc), and religious organizations and networks, with their rituals, social and cultural practices and civic outreach activities, are held to play an important part in this work. ${ }^{43}$ Marquardt et al, for example, in research on undocumented Latin American immigrants in the New American South, noted that in addition to the roles of congregations in immigrant advocacy and cross-cultural dialogue religious practices, narratives, and symbols assist migrants to make sense of their dislocation and resettlement, and allow them to carve out new spaces and alternative identities that help challenge their subordinate social location. ${ }^{44}$

David insists however that, in the case of Tamil Hindu women at the East Ham worshipping center, their networks and the capital that travels through them — goods, specialists, ritual knowledge, cultural practices — are fully transnational, not in the sense of a one-directional journey from South India to East London but in an ongoing process of circulation connecting worshippers with the mother temple and with centers and diasporic family and friends around the world. ${ }^{45}$ David's case draws attention, on the one hand, to the work of the women in preserving individual and communal Tamil Hindu-ness; on the other, this same work evidently contributes to producing both transnational Sri Lankan and global feminine Melmaruvathur identities. ${ }^{46}$ As Córdova Quero 
(in this volume) suggests, gender-role expectations are to some extent reinforced in such practices as women perform traditional roles of serving a male intermediary, connecting kin and conducting domestic worship. However, the context of transnational relations and perhaps also the disruption brought about by migration also allow women to emerge as spiritual innovators.

\section{Making Claims and Securing Public Spaces}

As I noted earlier, practices involve discourses, and vice versa. The printed guides to the conduct of puja, the crafting of floor designs, and the singing of bhajans that travel with devotees from India to London inform and authorize practices and contribute to the production of these female ritual experts. By and large, however, these discourses, with their associated representations and techniques, circulate within the transnational devotional community. In this section I move to the way in which migrant practices contribute to making external claims for recognition and rights and securing public spaces. Although my principal case relates to migrant practices in Malaysia, I return first to London's Tamil Hindus. Both cases focus on performative public displays at the time of religious festivals, notably on processions that, according to Kong, are among the most visible of religious activities in public spaces with the most opportunity for contact with secular authorities and with the religious practices of other faiths. ${ }^{47}$ In her account of the annual Tamil Hindu Thaipusam procession in Singapore, Kong notes the potential for the eruption of conflict, even violence, and the need to understand the local, national and transnational politics of such events including the memory of earlier processions, all relevant for the cases that follow. ${ }^{48}$

David illustrates the communal benefits but also the outreach potential of annual Tamil chariot events, such as the summer parade from the Shree Ghanapathy Temple through the streets of Wimbledon in South-West London, which attracts over 12,000 visitors. ${ }^{49}$ These large processions are designed "to affirm a sense of belonging and identity through expressions of solidarity and group cohesion for insiders (on a religious, social and cultural level), whilst at the same time, create recognition and visibility for outsiders or other onlookers.",50 
Such processions offer a public display of Hindu culture and identity, but also a necessary opportunity to engage with neighbors and negotiate with local agencies. Such practices of bridging and linking are not confined to the festival days themselves but must be cultivated throughout the year in order to build and secure public goodwill and effective community relations. ${ }^{51}$ The Wimbledon Temple, for example, works with official social service providers to prepare and distribute meals for the homeless and elderly, and offers volunteers for local conservation work. Regular meetings are held between festival organizers, local police and councilors, and community organizations. Risks are assessed, training provided, and organizers work with anti-terrorism officers. Civic and religious leaders are invited to attend the procession and surrounding events. Good relations have to be worked at and honed through a variety of diverse forms of service and bureaucratic practice.

David argues that, during chariot parades, "local streets are reformed and rearticulated, temporarily, into a Tamil sacrality, where Hindu deities can be witnessed by both Hindu devotees and interested bystanders, offering religious blessings (darshan) in a free, unhindered way to all present." ${ }^{, 52}$ As will be seen again in the Malaysian examples below, the sacralization of local space, together with enhanced visibility and the renewal of internal and external social relations all contribute to the high symbolic value that processions have for migrant minorities. Becoming visible and occupying public space through religious processions signifies a high level of group confidence as well as the endorsement of public bodies and local communities, and as such has to be managed with care.

This was clearly understood by Chinese Buddhist organizers of the night-time Wesak procession to the hill-top temple of Guan Yin in Kajang, a town on the outskirts of Kuala Lumpur: "Our aim is to bring Buddhist teaching from the temple to the households, to the people, to the town...They help us, we help them." 53 This occasion, in which Buddha images process through the town and up to the temple on floats accompanied by followers and onlookers, is preceded by an advertising campaign in Chinese, Malay and English and a launch ceremony with local dignitaries. 
It is followed by chanting and rituals at the temple, which attract thousands of visitors. Formally, Wesak celebrates the birth, enlightenment and death of Shakyamuni Buddha but, simultaneously, it puts the temple and the Buddhist organization that runs it on the map.

Although it is now recognized as an important local tradition, this procession only began in 1986. Its success as a tactic of public recognition was endorsed by a more recently established religious minority, the Christian Assembly of God, which decided to follow the example of local Buddhists and set up its own annual procession. Working with more than twenty other local churches, Catholic as well as Protestant and Pentecostal, it launched an ecumenical Easter March through the town. Aiming for maximum visibility and sonic impact, marchers wore red T-shirts and sang and prayed in unison. With Christians being a religious minority comprised of people from various new and old ethnic groups (Chinese, Indians, Indonesians and Africans as well as indigenous peoples of East Malaysia), the demonstration of a unified public presence was held to be a significant statement of Christian identity.

These public enactments were tolerated locally because they involved the temporary rather than permanent sacralization of space and, especially in the case of Wesak, significantly added to the tourist economy. They were highly localized performances that illustrate how, in Malaysia, settled as well as new communities - both of which continue to be cast as migrant religious minorities in a Malay-majority, Islam-dominated state - focus on the forging of religious placemaking in their struggle for space and recognition. ${ }^{54}$

\section{Crossing Boundaries and Performing Cosmopolitanism}

All the practices I have discussed above have involved practitioners connecting with both proximate and distant family and peers, and at times with outsiders. Hindus, Buddhists and Christians in Wimbledon and Kajang, as they make local claims and sacralize their neighbourhoods, necessarily extend themselves beyond the normal socio-spatial boundaries of community and congregation, temple and church. Furthermore, on the principal of strength in numbers, Kajang's 
Easter marchers realize the benefits of temporarily suspending their denominational differences to join together ecumenically to witness locally to their common Christian identity.

Established differences, however, whether religious or ethnic, more often enhance the separation and boundedness of groups than provide opportunities for boundaries to be transgressed. And, in the case of ecumenical, multi-ethnic and interfaith events, it can be tempting to overstate commonality and underrate the deep-seated nature of differences. In her study of Somali Muslim migrants in South Africa, in which she stresses the powerful communal experiences, explicit ethnoreligious identity and close ties of remittances and trade, Samadia Sadouni notes that ethno-national cleavages dominate at the expense of Muslim universalism. ${ }^{55}$ One of her Somali informants observed that, "You may find them all in the masjid (mosque) where...there are a thousand people...who all make salaat (prayer). But you can hardly see a Somali and Indian shaking hands." ${ }^{56}$ As Fiddian-Qasimiyeh and Qasimiyeh also note, with reference to the lack of interaction between Muslim asylum seekers and established Muslim settlers in the UK, a shared religious identity does not automatically break down other barriers to community participation. ${ }^{57}$

There are times, however, when tactical boundary crossing, temporary suspension of differences and the public performance of cosmopolitanism override customary divisions or strong claims for group affiliation, identity and recognition. Times of crisis, such as public grieving or remembrance, anti-war or anti-globalization protests, and times of celebration, including national days, celebrity weddings, sports events and charity fund-raisers, are examples. "Stop the War" protests before US and UK troops entered Iraq in 2003 brought together people from diverse faith backgrounds and none. ${ }^{58}$ Mass gatherings in British cities after the 7/7 bombings in 2005 , as well as providing opportunities for remembering the many innocent victims with messages, candles, thoughts and prayers, also became occasions for upholding local British Muslim communities caught up and implicated in a media storm of Islamophobia. ${ }^{59}$

London's New Year's Day Parade offers a rather different example, a time of celebration, for which I return to the Kimbanguists studied by David Garbin. ${ }^{60}$ Involving some 10,000 
performers representing some twenty countries, and including local community and religious groups from more than thirty London boroughs, one of the aims of the parade is to provide a global showcase for the iconic landmarks of central London - the Ritz, Piccadilly Circus, Trafalgar Square, and the Houses of Parliament. ${ }^{61}$ The "Fanfare Kimbanguiste" is one of hundreds of marching bands to participate in this ostensibly secular event organized with an eye on representing the "monumental glory" of London to the world's media. ${ }^{62}$ Extending their habitual liturgical practice of marching for God, band members understand themselves to be performing their faith, “spreading God's vibes ... all around where the devil has settled all his negativity," exemplifying moral piety and virtue, and bringing "Papa Simon" Kimbangu and the Congo to London. ${ }^{63}$ In addition, the younger marchers interpret their participation in the wider political contexts of intergenerational relations, race and racism, and multiculturalism. As well as their faithful performance, they see themselves disrupting "negative stereotypes associated with Congo and Congolese people, but also Black youth (masculinities) and black culture in the context of inner-city London especially after the summer riots of 2011."64 Videos, photos and comments on YouTube, Facebook and Flickr all confirm, through positive public reception, their capacity to cross conventional boundaries. These young marchers perform cosmopolitanism as they negotiate differences, transgress symbolic boundaries, and exercise cultural versatility. ${ }^{65}$

As some of the earlier examples have demonstrated, the religious practices of migrants frequently draw on the transnational circulation of people, things and ideas, and express diasporic relations: the case of Fanfare Kimbanguiste is no exception. However, in the performance of young Kimbanguists in particular, we see differences acknowledged and negotiated, and cultural versatility practiced:

Brass Band - people just think white people. This one was just different, it was only Black people. They see just gun and knife crime, that we are doing this, but actually even though there are stereotypes, we are trying hard to take the stereotypes away. ${ }^{66}$ 
The band lends its Congolese nationality, religious particularity, disciplined Black performance and African musical style to London's New Year's Day Parade and to other local carnivals and festivals, thus contributing to the public enactment of multicultural London. But young Kimbanguists, by "trying hard to take the stereotypes away", also embody and articulate a counterdiscourse which challenges some of the very boundaries (national, religious, racial and cultural) inherent in the logic of such events. ${ }^{67}$

\section{Conclusion}

The examples I have considered above illustrate the various types and scales of religious practice set out at the beginning of the chapter. We have seen regular religious routines, such as Christian prayer and temple puja, calendrical rites associated with Buddhist and Hindu festivals and processions, and quotidian practices informed by Hindu and Christian codes relating to dress and the domestic environment. Spiritual practices that are innovative or tailored to new circumstances, including the imitation of the hijra of the Prophet, novel healing and possession rituals and the personalization of specialized ritual roles, have been described, as have multicultural and ecumenical events. Some of these practices have been conducted by individuals and families in homes or places of worship; others have involved congregations or communities. Migrants' public practices, often tactical in their claims for recognition and space, have simultaneously been governed by wider society and its norms and discourses. Many of the migrant practitioners I have considered have drawn on practical and narrative traditions brought with them, and utilized people, objects and ideas from elsewhere. Some have been avowedly transnational in orientation, especially the Tamil Hindu worshippers at the London Sakthi Peetham; others, notably the Congolese Kimbanguists, have been diasporic in their embodiment of a global and prophetic vision centered on Nkamba. ${ }^{68}$

In addition to considering the range and types of living religious practices and the scales at which they operate, however, the principal aim of the chapter was to examine what migration and 
settlement bring to the wider picture of religious practice. I identified four processes to which such practices contribute. First, they enable migrants to migrate, travel, arrive and settle, with God, divine beings, spirits or prophets appealed to for help in clearing obstacles and providing material assistance. Secondly, they contribute to the formation of persons, and their religious and ethnic identities, as well as to the bonding of congregations and communities. Third, when religious practices are directed to public audiences and take place beyond the walls of places of worship and community centers, they may well constitute tactical initiatives for increased visibility, claims for recognition, and the temporary sacralization of public space. But, fourth, some practitioners go further, crossing social, religious and ethnic boundaries in order to move beyond established social divisions and the limitations of conventional cultural categories: they perform cosmopolitanism.

The focus here has been on the types and scales of religious practice and the ways in which everyday as well as calendrical practices address the challenges raised by migration. This has led to other issues being neglected, most notably the question of change. Religiously-inflected behavior in the home, in work, in health centers and schools — and organized religious practices are undoubtedly affected by the displacement, and social and cultural disruption that migration brings. But migrants are generally resilient and capable of adapting to new contexts and conditions. Opportunities as well as constraints arise as a consequence, such as ritual openings for lay people, new audiences for cultural performance, and occasions for service, or for acting together with religious others. How practitioners narrate and assign meanings to what they do may also change, with religious teachings and explanations at hand when needed, but alongside and in engagement with competing interpretations from secular sources. Living religious practices will be shaped by the readiness of migrants to negotiate with outsiders and cope with the limitations of their context, but also by their ability to develop effective tactics for addressing the challenges of migration and the requirement to integrate.

\section{Bibliography}


Baker, Chris. 2013. "The Contagion of the Sacred and the Right to the City: Modalities of Belonging, Becoming and Participating Amongst Diasporic Religious Communities and the Growth of the Post-Secular City." In Rescripting Religion in the City: Migration and Religious Identity in the Modern Metropolis, edited by Jane Garnett, and Alana Harris, 89101. Farnham and Burlington, VT: Ashgate.

Baumann, Gerd. 1996. Contesting Culture: Discourses of Identity in Multi-Ethnic London. Cambridge and New York: Cambridge University Press.

Certeau, Michel de. 1984. The Practice of Everyday Life. Berkeley: University of California Press. David, Ann R. 2010. "Gendering the Divine: New Forms of Feminine Hindu Worship.” International Journal of Hindu Studies 13(3): 337-355.

David, Ann R. 2012. “Sacralising the City: Sound, Space and Performance in Hindu Ritual Practices in London." Culture and Religion 13(4): 449-467.

Dessing, Nathal M., Jeldtoft, Nadia, Nielsen Jorgen S., and Linda Woodhead, eds. 2013. Everyday Lived Islam in Europe. Farnham and Burlington, VT: Ashgate.

Dessing, Nathal M. 2013. "How to Study Everyday Islam.” In Everyday Lived Islam in Europe, edited by Nathal M. Dessing, Nadia Jeldtoft, Jorgen S. Nielsen, and Linda Woodhead, 3952. Farnham and Burlington, VT: Ashgate.

DeWind, Josh and Manuel A. Vásquez. 2014. "The Religious Lives of Migrant Minorities: A MultiSited Transnational Perspective.” Global Networks 14(3): 251-272.

Fiddian-Qasmiyeh, Elena and Y. M. Qasmiyeh. 2010. "Muslim Asylum-Seekers and Refugees from the Middle East and North Africa: Negotiating Politics, Religion and Identity in the UK.” Journal of Refugee Studies 23(3): 294-314.

Flügel, Peter. 2012. “Jainism.” In Encyclopedia of Global Studies. Vol. 3 edited by Helmut K. Anheier, and Mark Juergensmeyer, 975-979. Thousand Oakes: Sage.

Gallo, Esther, ed. 2014. Migration and Religion in Europe: Comparative Perspectives on South Asian Experiences. Farnham and Burlington, VT: Ashgate. 
Garbin, David. 2010. "Embodied Spirit(s) and Charismatic Power among Congolese Migrants in London.” In Summoning the Spirits: Possession and Invocation in Contemporary Religion, edited by Andrew Dawson, 46-57. London: I.B. Tauris.

Garbin, David. 2012. “'Marching for God' in the Global City: Public Space, Religion, and Diasporic Identities in a Transnational African Church." Culture and Religion 13(4): 435447.

Gilliat-Ray, Sophie. 2010. Muslims in Britain: An Introduction. Cambridge: Cambridge University Press.

Hall, David D. ed. 1997. Lived Religion in America: Toward a History of Practice. Princeton: Princeton University Press.

Hansen, Thomas Blom. 2009. "In Search of God's Hand: On Masculinity and Religion.” In Pieties and Gender, edited by Lene Sjørup, and Hilda Rømer Christensen, 123-142. Leiden: Brill.

Hansen, Thomas Blom. 2012. Melancholia of Freedom: Anxiety, Race and Everyday Life in a South African Township. Princeton: Princeton University Press.

Hüwelmeier, Gertrud, and Kristine Krause, eds. 2010. Traveling Spirits: Migrants, Markets and Mobilities. New York and London: Routledge

Jeannerat, Caroline. 2009. “Of Lizards, Misfortune and Deliverance: Pentecostal Soteriology in the Life of a Migrant.” African Studies 68(2): 251-271.

Jeffrey, Craig, and Colin McFarlane. 2008. “Performing Cosmopolitanism.” Environment and Planning D: Society and Space 26(3): 420-427.

Jeldtoft, Nadia. 2013. “Spirituality and Emotions: Making a Room of One’s Own.” In Everyday Lived Islam in Europe, edited by Nathal M. Dessing, Nadia Jeldtoft, Jorgen S. Nielsen, and Linda Woodhead, 85-100. Farnham and Burlington, VT: Ashgate.

Johnson, Paul Christopher, 2007. Diaspora Conversions: Black Carib Religion and the Recovery of Africa. Berkeley: University of California Press. 
Knott, Kim, 1986. Hinduism in Leeds: Religious Practice in the Indian Hindu Community and in Hindu-Related Groups. Leeds: Community Religions Project.

Knott, Kim. 2005. The Location of Religion: A Spatial Analysis. London and Oakville CT: Equinox. Kong, Lily. 2005. "Religious Processions: Urban Politics and Poetics.” Temenos: Nordic Journal of Comparative Religion 41(2): 225-249.

Levitt, Peggy. 2007. God Needs no Passport: Immigrants and the Changing American Religious Landscape. New York: New Press.

Levitt, Peggy. 2013. "Religion on the Move." In Religion on the Edge: De-centering and Recentering the Sociology of Religion, edited by Courtney Bender, Wendy Cadge, Peggy Levitt, and David Smilde, 159-76. New York: Oxford University Press.

Marquardt, Marie Friedmann, Steigenga, Timothy J., Williams, Philip J., and Manuel A.Vasquez. 2011. Living “Illegal”: The Human Face of Unauthorized Immigration. New York: New Press.

McLoughlin, Seán. 2013. "Religion, Religions and Diaspora.” In A Companion to Diaspora and Transnationalism, edited by Ato Quayson and Girish Daswani, 125-138. Oxford and Cambridge, MA: Blackwell.

Mountain of Fire and Miracles Ministries. 2014. Accessed January 20. http://www.mountainoffire.org/.

Orsi, Robert. 2005. Between Heaven and Earth: The Religious Worlds People Make and the Scholars who Study Them. Princeton: Princeton University Press.

Pieterse, Jan Nedeverveen. 2003. "Social Capital and Migration: Beyond Ethnic Economies." Ethnicities 3(1): 25-58.

Sadouni, Samadia. 2009. “'God is not Unemployed': Journeys of Somali Refugees in Johannesburg.” African Studies 68 (2): 235-249.

Stringer, Martin. 2013. Discourses of Religious Diversity: Explorations in an Urban Ecology. Farnham and Burlington, VT: Ashgate. 
Tweed, Thomas A. 1997. Our Lady of the Exile: Diasporic Religion at a Cuban Catholic Shrine in Miami. New York and Oxford: Oxford University Press.

Tweed, Thomas A. 2006. Crossing and Dwelling: A Theory of Religion. Cambridge, MA: Harvard University Press.

Vásquez, Manuel A. 2009. “The Global Portability of Pneumatic Christianity: Comparing African and Latin American Pentecostalisms.” African Studies 68 (2): 273-286.

Vásquez, Manuel A. 2011. More than Belief: A Materialist Theory of Religion. New York: Oxford University Press.

Vásquez, Manuel A., and Kim Knott. 2014. “Three Dimensions of Religious Place-Making in Diaspora." Global Networks 14(3): 326-347.

Williams, Raymond Brady. 1984. A New Face of Hinduism: The Swaminarayan Religion. Cambridge: Cambridge University Press.

Wong, Diana and Levitt, Peggy. 2014. "Traveling Faiths and Migrant Religions: The Case of Circulating Models of Religious Da'wa among the Tablighi Jamaat and Foguangshan in Malaysia." Global Networks 14(3): 348-362.

Woodhead, Linda. 2013. “Tactical and Strategic Religion.” In Everyday Lived Islam in Europe, edited by Nathal M. Dessing, Nadia Jeldtoft, Jorgen S. Nielsen, and Linda Woodhead, 9-22. Farnham and Burlington, VT: Ashgate.

\footnotetext{
${ }^{1}$ Straut Eppsteiner and Hagan, this volume.

${ }^{2}$ David D. Hall, ed., Lived Religion in America: Toward a History of Practice (Princeton: Princeton University Press 1997); Nathal M. Dessing, Nadia Jeldtoft, Jorgen S. Nielsen and Linda Woodhead, eds., Everyday Lived Islam in Europe (Farnham and Burlington, VT: Ashgate, 2013).

3 "The Religious Lives of Migrant Minorities," funded by the Migration Program of the Social Science Research Council with support from the Ford Foundation, directed by Josh deWind. The project was coordinated by Jose Casanova, Peggy Levitt and Manuel Vásquez, with eleven researchers in three national teams (including Caroline Jeannerat, Samadia Sadouni, David Garbin, Ann David, and a Malaysian research team led by Diana Wong). I was one of four international advisors.

${ }^{4}$ Josh DeWind and Manuel A. Vásquez, "The Religious Lives of Migrant Minorities: A Multi-Sited Transnational Perspective," Global Networks 14, no. 3 (2014): 251-272.
} 
${ }^{5}$ Gerd Baumann, Contesting Culture: Discourses of Identity in Multi-Ethnic London (Cambridge and New York: Cambridge University Press, 1996); Martin Stringer, Discourses of Religious Diversity: Explorations in an Urban Ecology (Farnham and Burlington, VT: Ashgate, 2013); Manuel A. Vásquez, More than Belief: A Materialist Theory of Religion (New York: Oxford University Press, 2011).

${ }^{6}$ Stringer, Discourses, 142-147.

${ }^{7}$ Kim Knott, The Location of Religion: A Spatial Analysis (London and Oakville CT: Equinox, 2005); Thomas A. Tweed, Our Lady of the Exile: Diasporic Religion at a Cuban Catholic Shrine in Miami (New York and Oxford: Oxford University Press, 1997); Thomas A. Tweed, Crossing and Dwelling: A Theory of Religion (Cambridge, MA: Harvard University Press, 2006); Vásquez, More than Belief.

${ }^{8}$ Tweed, Our Lady, 15; Tweed, Crossing, 80-81.

${ }^{9}$ Dessing et al, Everyday; Robert Orsi, Between Heaven and Earth: The Religious Worlds People Make and the Scholars who Study Them (Princeton: Princeton University Press, 2005).

${ }^{10}$ Ann R. David, "Gendering the Divine: New Forms of Feminine Hindu Worship," International Journal of Hindu Studies 13, no. 3 (2010): 337-355; Esther Gallo, ed., Migration and Religion in Europe: Comparative Perspectives on South Asian Experiences (Farnham and Burlington, VT: Ashgate, 2014).

${ }^{11}$ Gallo, Migration and Religion.

${ }^{12}$ Michel de Certeau, The Practice of Everyday Life (Berkeley: University of California Press, 1984); Dessing et al, Everyday; Linda Woodhead, "Tactical and Strategic Religion," in Everyday Lived Islam in Europe, eds. Nathal M. Dessing et al (Farnham and Burlington, VT: Ashgate, 2013) 20.

${ }^{13}$ Kim Knott, Hinduism in Leeds: Religious Practice in the Indian Hindu Community and in HinduRelated Groups (Leeds: Community Religions Project, 1986); Nathal M. Dessing, "How to Study Everyday Islam," in Everyday Lived Islam in Europe, eds. Nathal M. Dessing et al (Farnham and Burlington, VT: Ashgate, 2013); Nadia Jeldtoft, "Spirituality and Emotions: Making a Room of One's Own," in Everyday Lived Islam in Europe, eds. Nathal M. Dessing et al (Farnham and Burlington, VT: Ashgate, 2013).

${ }^{14}$ Dessing et al, Everyday; Gallo, Religion and Migration.

${ }^{15}$ Gertrud Hüwelmeier and Kristine Krause, eds. Traveling Spirits: Migrants, Markets and Mobilities (New York and London: Routledge, 2010); Paul Christopher Johnson, Diaspora Conversions: Black Carib Religion and the Recovery of Africa (Berkeley: University of California Press, 2007); Peggy Levitt, "Religion on the Move," in Religion on the Edge: De-centering and Recentering the Sociology of Religion, eds. Courtney Bender et al (New York: Oxford University Press, 2013): 159-76; Seán McLoughlin, "Religion, Religions and Diaspora," in A Companion to Diaspora and Transnationalism, eds. Ato Quayson and Girish Daswani (Oxford and Cambridge, MA: Blackwell, 2013): 125-138.

${ }^{16}$ Data and quotations for this example are from fieldwork conducted by Caroline Jeannerat. Caroline Jeannerat, "Of Lizards, Misfortune and Deliverance: Pentecostal Soteriology in the Life of a Migrant," African Studies 68, no. 2 (2009): 251-271; cf. Manuel A. Vásquez and Kim Knott, "Three Dimensions of Religious Place-Making in Diaspora," Global Networks 14, no. 3 (2014): 326-347.

${ }^{17}$ Jeannerat, "Of Lizards"; Vásquez and Knott, "Three Dimensions".

${ }^{18}$ MFM Prayer Points, http://www.mountainoffire.org/.

${ }^{19}$ Vásquez and Knott, "Three Dimensions," 333.

${ }^{20}$ Jeannerat, "Of Lizards," 251.

${ }^{21}$ Vásquez and Knott, "Three Dimensions," 335.

${ }^{22}$ Vásquez and Knott, "Three Dimensions," 336.

${ }^{23}$ Data and quotations for this example come from fieldwork conducted by David Garbin; cf. Vásquez and Knott, "Three Dimensions." 
${ }^{24}$ Levitt, "Religion on the Move."

${ }^{25}$ Diana Wong and Peggy Levitt, "Traveling Faiths and Migrant Religions: The Case of Circulating Models of Religious Da'wa among the Tablighi Jamaat and Foguangshan in Malaysia," Global Networks 14, no. 3 (2014): 348-362; Levitt, "Religion on the Move."

${ }^{26}$ Levitt, "Religion on the Move"; Manuel A. Vásquez, "The Global Portability of Pneumatic Christianity: Comparing African and Latin American Pentecostalisms," African Studies 68, no. 2 (2009): 273-286.

${ }^{27}$ Vásquez, "Global Portability," 277.

${ }^{28}$ Peter Flügel, “Jainism,” in Encyclopedia of Global Studies. Vol. 3, eds. Helmut K. Anheier and Mark Juergensmeyer (Thousand Oakes: Sage, 2012), 976.

${ }^{29}$ Flügel, "Jainism," 976.

${ }^{30}$ Raymond Brady Williams, A New Face of Hinduism: The Swaminarayan Religion (Cambridge: Cambridge University Press, 1984).

${ }^{31}$ David Garbin, "Embodied Spirit(s) and Charismatic Power among Congolese Migrants in London," in Summoning the Spirits: Possession and Invocation in Contemporary Religion, ed.

Andrew Dawson (London: I.B. Tauris, 2010), 42.

${ }^{32}$ Garbin, "Embodied Spirit(s)," 49.

${ }^{33}$ Garbin, "Embodied Spirit(s)," 51.

${ }^{34}$ Quotation from Pastor G, from fieldwork conducted by David Garbin; also cited in Garbin, "Embodied Spirit(s)," 52.

${ }^{35}$ Thomas Blom Hansen, "In Search of God's Hand: On Masculinity and Religion," in Pieties and Gender, eds. Lene Sjørup and Hilda Rømer Christensen (Leiden: Brill, 2009): 123-142; David, "Gendering the Divine."

${ }^{36}$ Hansen, "In Search of God's Hand," 136.

${ }^{37}$ Hansen, "In Search of God's Hand," 138.

${ }^{38}$ David, "Gendering the Divine."

${ }^{39}$ David, "Gendering the Divine," 338.

${ }^{40}$ David, "Gendering the Divine," 339.

${ }^{41}$ David, "Gendering the Divine," 340.

42 David, "Gendering the Divine," 341.

${ }^{43}$ Jan Nedeverveen Pieterse, "Social Capital and Migration: Beyond Ethnic Economies," Ethnicities 3, no. 1 (2003): 25-58; Chris Baker, "The Contagion of the Sacred and the Right to the City: Modalities of Belonging, Becoming and Participating Amongst Diasporic Religious Communities and the Growth of the Post-Secular City," in Rescripting Religion in the City: Migration and Religious Identity in the Modern Metropolis, eds. Jane Garnett, and Alana Harris (Farnham and Burlington, VT: Ashgate, 2013), 89-101; Peggy Levitt, God Needs no Passport: Immigrants and the Changing American Religious Landscape (New York: New Press, 2007).

${ }^{44}$ Marie Friedmann Marquardt, Timothy J. Steigenga, Philip J. Williams and Manuel A. Vásquez, Living "Illegal": The Human Face of Unauthorized Immigration (New York: New Press, 2011).

${ }^{45}$ David, "Gendering the Divine," 344.

${ }^{46}$ David, "Gendering the Divine," 350.

${ }^{47}$ Lily Kong, "Religious Processions: Urban Politics and Poetics," Temenos: Nordic Journal of Comparative Religion 41, no. 2 (2005): 225.

${ }^{48}$ Kong, "Religious Processions," 226, 231-2.

${ }^{49}$ Ann R. David, "Sacralising the City: Sound, Space and Performance in Hindu Ritual Practices in London," Culture and Religion 13, no. 4 (2012): 449-467.

${ }^{50}$ David, "Sacralising the City," 454.

${ }^{51}$ Pieterse, "Social Capital and Migration"; David, "Sacralising the City," 461.

${ }^{52}$ David, "Sacralising the City," 463. 
${ }^{53}$ From an interview with Lee, the lay leader of the Pertubuhan Budhis Manju Suddhi, May 2007. Data and vignettes for this case study provided by Diana Wong and the Malaysia research team; also quoted in Vásquez and Knott, "Three Dimensions," 339.

${ }^{54}$ Vásquez and Knott, "Three Dimensions".

${ }^{55}$ Samadia Sadouni, “God is not Unemployed': Journeys of Somali Refugees in Johannesburg," African Studies 68, no. 2 (2009): 242.

${ }^{56}$ From a Somali Muslim informant, from fieldwork conducted by Samadia Sadouni; also quoted in Sadouni, "God is not Unemployed," 242.

${ }^{57}$ Elena Fiddian-Qasmiyeh and Y. M. Qasmiyeh, "Muslim Asylum-Seekers and Refugees from the Middle East and North Africa: Negotiating Politics, Religion and Identity in the UK," Journal of Refugee Studies 23, no. 3 (2010): 294-314.

${ }^{58}$ Sophie Gilliat-Ray, Muslims in Britain: An Introduction (Cambridge: Cambridge University Press, 2010).

${ }^{59}$ Gilliat-Ray, Muslims in Britain.

${ }^{60}$ David Garbin, "Marching for God' in the Global City: Public Space, Religion, and Diasporic Identities in a Transnational African Church," Culture and Religion 13, no. 4 (2012): 435-447.

${ }^{61}$ Garbin, "Marching for God," 426.

${ }^{62}$ Garbin, "Marching for God," 426.

${ }^{63}$ From a Congolese Kimbanguist informant, from fieldwork conducted by David Garbin, as cited in Garbin, "Marching for God," 435-437.

${ }^{64}$ Garbin, "Marching for God," 443.

${ }^{65}$ Craig Jeffrey and Colin McFarlane, "Performing Cosmopolitanism," Environment and Planning D: Society and Space 26:3 (2008) 420-421.

${ }^{66}$ From a Congolese Kimbanguist informant, Garbin, "Marching for God," 443.

${ }^{67}$ Garbin, "Marching for God," 443.

${ }^{68}$ For more on "diasporic" and "transnational" see Cherry, this volume. 